\title{
Dual Control of the gua Operon of Escherichia coli K 12 by Adenine and Guanine Nucleotides
}

\author{
By R. K. MEHRA† AND W. T. DRABBLE* \\ Department of Biochemistry, University of Southampton, Southampton SO9 $3 T U$
}

(Received 7 August 1980)

The gua operon of Escherichia coli $\mathrm{K} 12$ comprises structural genes for the two enzymes, IMP dehydrogenase and GMP synthetase, required for the biosynthesis of GMP from IMP. The specific activities of these enzymes were measured in various purine auxotrophs. GuaA and guaB mutants (guanine-specific) were derepressed under conditions of growth limitation by guanine but were repressed by excess guanine. This suggests that formation of the enzymes is normally controlled by a guanine nucleotide. Derepression of the operon in purine-starved pur mutants depended on the type of mutant and on whether adenine or guanine was provided. A purA strain (adenine-specific) and strains with early blocks in purine biosynthesis (purF and purD) did not derepress. PurE or purC strains [5'-phosphoribosyl5-aminoimidazole (AIR)-accumulating] derepressed only 4-fold. The operon was repressed in purH strains [5'-phosphoribosyl-5-amino-4-imidazolecarboxamide (AICAR)-accumulating] grown with limiting guanine or hypoxanthine, but derepressed by growth with limiting adenine. Two mutants (purA guaA and purA guaB) which can neither synthesize AMP and GMP de novo, nor interconvert them, were isolated. The specific activity of IMP dehydrogenase in one of these strains grown with different concentrations of guanine and adenine revealed that adenine induces the gua operon whereas guanine represses it. Intracellular purine nucleotide pools were measured in a purH mutant repressed (guaninegrown) and derepressed (adenine-grown) for IMP dehydrogenase. The guanylate pool was similar under the two growth conditions; however, the adenylate pool of the adenine-grown bacteria was two to three times greater than that of the guanine-grown cells. A dual mechanism for regulating expression of the gua operon, involving induction by AMP and repression by GMP, is proposed.

\section{INTRODUCTION}

Although the purine nucleotide pool of Escherichia coli provides precursors for several low molecular weight metabolites (Fig. 1), the major flux through this pool during balanced growth is directed into nucleic acid biosynthesis. [The total nucleic acid content of $E$. coli is about $150 \mu \mathrm{g}$ (mg dry wt) ${ }^{-1}$ (Luria, 1960) of which some $52 \%$ is adenine plus guanine nucleotides, i.e. $78 \mu \mathrm{g}(\mathrm{mg} \text { dry } \mathrm{wt})^{-1}$. The total free endogenous adenylate plus guanylate pool is about $5 \mu \mathrm{g}(\mathrm{mg} \text { dry } \mathrm{wt})^{-1}$.] The molar ratio of adenine to guanine nucleotides in the nucleic acids of $E$. coli is approximately one (Davidson, 1976); therefore the separate pathways to these two precursors must be coordinately regulated to produce AMP and GMP in about equal amounts. This regulation is achieved, in part, by directly modifying the activities of various key enzymes. Thus, IMP dehydrogenase is feedback-inhibited by GMP and activated by AMP (Mager \& Magasanik, 1960; Gilbert et al., 1979; Nijkamp, 1969) and adenylosuccinate synthetase is inhibited by AMP (Wyngaarden \& Greenland, 1963). The

$\dagger$ Present address: Department of Biochemistry, University College, Galway, Eire. 


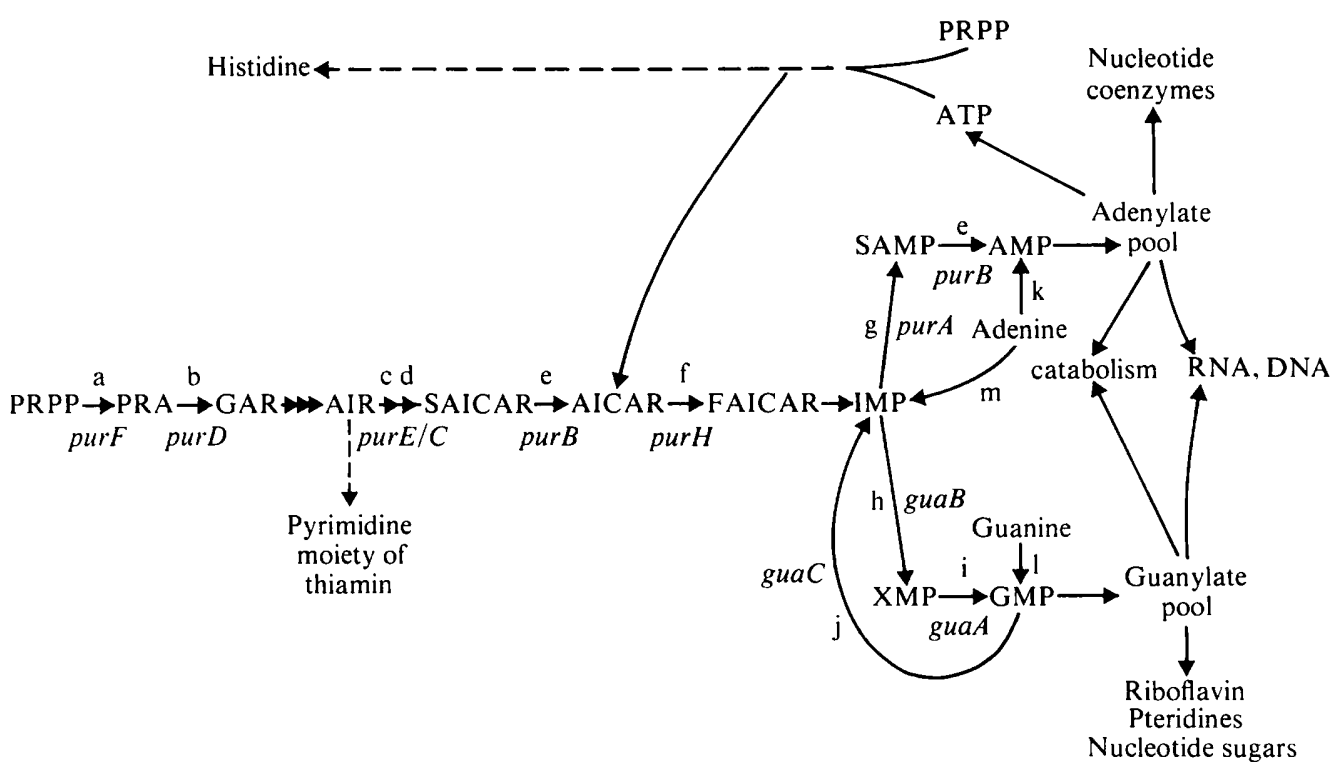

Fig. 1. Purine nucleotide metabolism in Escherichia coli.

Abbreviations: PRPP, 5-phosphoribosyl diphosphate: PRA, 5-phosphoribosylamine: GAR, 5'-phosphoribosylglycinamide: AIR, 5'-phosphoribosyl-5-aminoimidazole: SAICAR, 5'-phosphoribosyl-5-amino-4-imidazole- $N$-succinocarboxamide; AICAR, 5'-phosphoribosyl-5-amino-4-imidazolecarboxamide: FAICAR, 5'-phosphoribosyl-5-formamido-4-imidazolecarboxamide: IMP, inosine 5'-monophosphate: SAMP, adenylosuccinate: XMP, xanthosine 5'-monophosphate: AMP, adenosine 5'-monophosphate; GMP, guanosine 5'-monophosphate.

The structural gene designations correspond to the enzymes: PRPP amidotransferase (a), GAR synthetase (b), AIR carboxylase (c), SAICAR synthetase (d), SAMP lyase (e), AICAR transformylase (f), SAMP synthetase (g). IMP dehydrogenase (h), GMP synthetase (i). GMP reductase (j). Enzymes (k) and (l) are adenine and guanine phosphoribosyltransferases, respectively, and route $(\mathrm{m})$ involves the enzymes adenosine deaminase and inosine kinase.

degradative enzymes adenosine deaminase and GMP reductase are inhibited by 5'-phosphoribosyl-5-amino-4-imidazolecarboxamide (AICAR) and by ATP, respectively (Kuramitsu et al.. 1964: Mager \& Magasanik, 1960). Some coordination between the two pathways must also result from the requirement of adenylosuccinate synthetase for GTP and of GMP synthetase for ATP. Balanced synthesis of AMP and GMP is, in addition, maintained by controlling the cellular concentrations of enzymes involved in their formation. Both adenylosuccinate synthetase and adenylosuccinate lyase are repressed by adenine nucleotides (Nierlich \& Magasanik, 1971). The control of IMP dehydrogenase and GMP synthetase formation is the subject of this report.

IMP dehydrogenase and GMP synthetase are the products of the structural genes guaB and guaA, respectively, of the gua operon (Nijkamp \& DeHaan, 1967; Lambden \& Drabble, 1973). Expression of the gua operon has been studied previously by starvation experiments, that is, by measuring the activities of the enzymes in guaA and guaB mutants grown under conditions of guanine limitation (Nijkamp \& DeHaan, 1967; Nierlich \& Magasanik, 1971; Lambden \& Drabble, 1973). These experiments have established that the operon is repressed by guanine nucleotides. There is some evidence to suggest that a supply of adenine nucleotides is necessary for maximal expression of the gua operon. A purH mutant (blocked prior to IMP formation and therefore unable to synthesize de novo either AMP or GMP, Fig. 1) did not produce derepressed levels of IMP dehydrogenase and GMP synthetase when 
Table 1. Purine auxotrophs of Escherichia coli K12

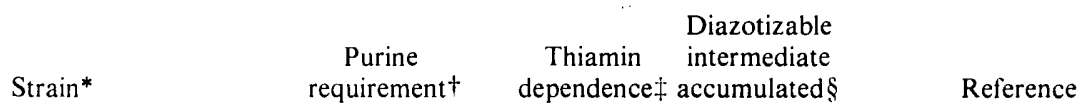

RM1003 ( purA503)

RM 1008 (purA503 guaB506)"

RM 1009 (purA 503 guaA508)॥

PL1068 (guaA48)

PL1075 ( purD55)

PL1080 ( pur-60)

PL1086 ( purH66)

PL1098 ( purF78)

PL1110 (purH90)

PL.11 19 ( pur-99)

PL1138 (guaB 105)

$\mathrm{MW} 1047$ ( purA747)

$$
\text { A }
$$

$A$ and either $G$ or $X$

$A$ and $\mathrm{G}$

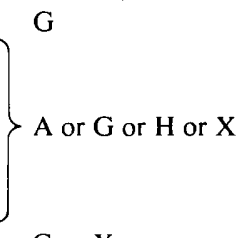

G or $\mathrm{X}$

A

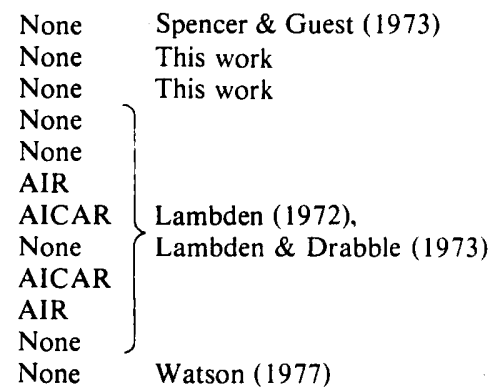

* PurH9O and pur-99 were induced by the frameshift mutagen ICR372, guaB105 by ethyl methanesulphonate, and all other mutations by $N$-methyl- $N^{\prime}$-nitro- $N$-nitrosoguanidine. PL1080 and PL1119 are either purE or purC mutants.

+ A, adenine; G, guanine; H, hypoxanthine; X, xanthine.

+ Some purine auxotrophs blocked before IMP require thiamin when grown in adenine-supplemented medium (Watson \& Drabble, 1975).

$\S$ Detected by the Bratton-Marshall test.

RM 1008 and PL1138 lack IMP dehydrogenase activity; RM 1009 lacks GMP synthetase activity.

cultured under conditions of guanine limitation (Nijkamp, 1969). Furthermore, a guaninestarved double mutant unable to synthesize de novo AMP and GMP and unable to convert AMP to GMP (purC guaB or purC guaA) did not derepress unless adenine was added to the growth medium (Nijkamp. 1969).

In this report, we extend earlier experiments by examining the expression of the gua operon in a series of purine auxotrophs blocked at various points in nucleotide biosynthesis. A well-defined correlation is observed between the extent of derepression of the gua operon, the concentrations of adenine and/or guanine provided in the culture medium, and the relative sizes of intracellular AMP and GMP pools. We conclude that the gua operon is controlled by a dual mechanism involving both adenine and guanine nucleotides.

\section{METHODS}

Bacterial strains. Escherichia coli $\mathrm{K} 12$ strain $\mathrm{W} 3110$ was the prototrophic parent of the purine auxotrophs listed in Table 1. Working stocks were maintained on nutrient agar (supplemented with $20 \mu \mathrm{g} \mathrm{m}^{-1}$ each of adenine and guanine) and were kept at $4{ }^{\circ} \mathrm{C}$; they were subcultured every 6 months. The phenotypes of all mutants were checked immediately before use.

Media. Defined salts medium (minimal medium) was that of Davis \& Mingioli (1950), containing glucose (final concentration $2 \mathrm{mg} \mathrm{ml}^{-1}$ ) as carbon source. Minimal agar was prepared with $1 \%(\mathrm{w} / \mathrm{v})$ Ionagar (Oxoid, code L12). Purines, when required, were added to media at a final concentration of $20 \mu \mathrm{g} \mathrm{ml}^{-1}$, unless stated otherwise. Thiamin was used at a final concentration of $5 \mu \mathrm{g} \mathrm{ml}^{-1}$. Nutrient broth was Oxoid, code CM67, and nutrient agar was Oxoid, code CM3.

Chemicals. Adenosine 5'-triphosphate (disodium salt, trihydrated), $\beta$-NAD ${ }^{+}$and glutathione (reduced) were obtained from Boehringer. Adenosine $5^{\prime}$-diphosphate (trisodium salt), xanthosine $5^{\prime}$-monophosphate and 2-(4'-tert-butylphenyl)-5-(4"-biphenylyl)-1,3,4-oxadiazole (butyl-PBD) were from Koch-Light. $N$-Methyl- $N^{\prime}$ nitro- $N$-nitrosoguanidine (NG) was obtained from Raiph $\mathrm{N}$. Emanuel (Wembley, HA0 1PY). $\left[8^{-14} \mathrm{C} \mid \mathrm{Adenine}\right.$ (specific radioactivity $54.2 \mathrm{mCi} \mathrm{mmol}^{-1}, 2.00 \mathrm{GBq} \mathrm{mmol}^{-1}$ ) and $\left[88^{-14} \mathrm{C}\right.$ guanine (specific radioactivity $50 \mathrm{mCi}$ $\mathrm{mmol}^{-1}, 1.85 \mathrm{GBq} \mathrm{mmol}^{-1}$ ) were from The Radiochemical Centre, Amersham. All other chemicals were from BDH. 
Isolation of mutants. Mutagenesis with NG and the penicillin screening techniques used have been described by Lambden \& Drabble (1973). Strains RM1008 (purA guaB) and RM1009 (purA guaA) were derived from RM1003 (purA) by further NG mutagenesis followed by penicillin screening for strains with a specific requirement for adenine plus guanine. Gua mutations were confirmed by assays for IMP dehydrogenase and GMP synthetase and the purA mutation by the Bratton-Marshall test (see below).

Bacterial growth measurements. Bacterial mass was measured spectrophotometrically at $650 \mathrm{~nm}$ using a Pye Unicam SP600 spectrophotometer.

Growth of cultures and preparation of cell-free extracts. The general methods for growing cultures and preparing cell-free extracts have been described previously (Lambden \& Drabble, 1973).

Enzyme assays. Assays for IMP dehydrogenase (EC 1.2.1.14), GMP synthetase (XMP aminase) (EC 6.3.4.1) and for protein were described by Lambden \& Drabble (1973).

Detection of diazotizable amines. A modified procedure for the Bratton-Marshall test (Gots \& Gollub, 1957) was used to detect the accumulation of diazotizable amines in culture media. Bacteria were grown in minimal medium containing the required purine supplement. A sample $(2 \mathrm{ml})$ was centrifuged to remove bacteria and $2 \mathrm{ml}$ trichloroacetic acid $(7.5 \%, \mathrm{w} / \mathrm{v})$ was added to the supernatant, followed by $0.4 \mathrm{ml} 0.2 \%(\mathrm{w} / \mathrm{v})$ sodium nitrite with mixing. After $30 \mathrm{~s}, 0.4 \mathrm{ml} 0.5 \%(\mathrm{w} / \mathrm{v})$ sodium sulphamate was added with mixing. After a further $30 \mathrm{~s}, 0.4 \mathrm{ml}$ $0.1 \%(\mathrm{w} / \mathrm{v}) \mathrm{N}$-1-naphthylethylenediamine dihydrochloride in $0.01 \mathrm{M}-\mathrm{HCl}$ was added to develop the colour. The presence of AIR (see Fig. 1 for definition of abbreviations) derivatives in the culture supernatant produces a deep orange colour. SAICAR and AICAR derivatives produce a purple colour. FAICAR was detected following hydrolysis to AICAR by boiling with $1.5 \mathrm{M}^{-} \mathrm{H}_{2} \mathrm{SO}_{4}$ for $10 \mathrm{~min}$.

Extraction of intracellular purine nucleotides. Samples $(10 \mathrm{ml})$ taken from cultures were filtered by suction through $25 \mathrm{~mm}$ diam. Millipore filters (type HA, $0.45 \mu \mathrm{m}$ pore size). The intracellular nucleotides were extracted by a modification of the procedure of Nazar et al. (1970). Each filter was washed by passing through $2 \mathrm{ml}$ ice-cold minimal medium and then quickly immersed in $5.5 \mathrm{ml}$ ice-cold $1 \mathrm{M}$-acetic acid. After $5 \mathrm{~min}$ of gentle agitation the suspension of bacteria was freeze-thawed three times with $5 \mathrm{~min}$ periods of agitation between freezes. A $5 \mathrm{ml}$ sample of this acid extract was lyophilized, resuspended in $0.2 \mathrm{ml}$ cold distilled water and centrifuged at $1000 \mathrm{~g}$ for $5 \mathrm{~min}$ to remove insoluble material. The nucleotides in the supernatant were analysed by thin-layer chromatography.

Thin-layer chromatography (t.l.c.) of nucleotides. Two-dimensional t.l.c. was used to separate all the radioactive purine nucleotides in one sample. A $20 \mu \mathrm{l}$ portion of the extract was spotted on to a $200 \times 200 \mathrm{~mm}$ polyethyleneimine cellulose t.l.c. plate (Schleicher \& Schull) containing a fluorescent indicator, together with $5 \mu$ l of a mixture of purine nucleotides (AMP, GMP, IMP, XMP, ADP, GDP, ATP, GTP, each $1 \mathrm{mM}$ ) to serve as markers. The nucleotide spots could then be located by their ultraviolet absorption under a Hanovia 'Chromatolite' ( $245 \mathrm{~nm}$ peak emission). T.l.c. plates were washed for $15 \mathrm{~min}$ in $500 \mathrm{ml}$ methanol, to remove any interfering salt in the applied sample, and dried in a stream of air. The solvent system of Neuhard \& Munch-Peterson (1966) was used to develop the plates in closed tanks (first dimension $-1 \mathrm{M}-\mathrm{LiCl}$ in $1 \mathrm{M}$-acetic acid, plates then dried and washed in methanol; second dimension $-3 \mathrm{M}$-ammonium acetate in $5 \%(\mathrm{w} / \mathrm{v})$ boric acid, $\mathrm{pH} 7 \mathrm{l}$. The area around each separate nucleotide spot was scraped away and the spots were wetted with distilled water. The wet material from individual spots was quantitatively transferred to $10 \mathrm{ml}$ butyl-PBD scintillation fluid $[8 \mathrm{~g}$ butyl-PBD in toluene (sulphur-free)/methanol; $3: 1, \mathrm{v} / \mathrm{v}$. A Philips liquid-scintillation analyser was used to count radioactivity. Areas of the developed chromatogram between closely running nucleotide spots were found to be free from radioactive contamination. Intracellular purine nucleotide pools are expressed as nmol per $\mathrm{mg}$ dry weight of bacteria. Dry weight was determined from a calibration curve relating dry weight to turbidity $\left(A_{650}\right)$.

\section{RESULTS}

\section{Expression of the gua operon in purine auxotrophs}

The activities of IMP dehydrogenase and GMP synthetase were measured in cell-free extracts of mutants blocked at various points in purine biosynthesis. The bacteria were provided with either growth-limiting adenine or guanine (Table 2).

Mutants defective in the biosynthesis of IMP from PRPP (see Fig. 1) can still synthesize AMP and GMP from IMP. Either adenine or guanine serves as purine source because AMP and GMP can be interconverted (Fig. 1). Strains with early blocks in the purine pathway were not derepressed (PL1075) or showed only slight derepression (PL1098). AIR-accumulating mutants were about 4 -fold derepressed by growth with either purine. The AICARaccumulating strains were derepressed for both enzymes when grown with limiting adenine but were repressed with limiting guanine (or with limiting hypoxanthine or excess adenine). 
Table 2. Expression of the gua operon in purine auxotrophs

Cultures were grown and enzymes assayed as described by Lambden \& Drabble (1973). Adenine or guanine was added to the culture medium to a final concentration of $4 \mu \mathrm{g} \mathrm{m}^{-1}$ unless indicated otherwise. All adenine-grown cultures were supplemented with thiamin (final concentration $5 \mu \mathrm{g} \mathrm{ml}^{-1}$ ). Enzyme derepression $(D)$ is expressed relative to wild-type cells $(D=1)$ grown in minimal medium IIMP dehydrogenase: $12 \mathrm{nmol}$ XMP $\min ^{-1}$ (mg protein) ${ }^{-1}$ (average of 40 assays); GMP synthetase: $15 \mathrm{nmol}$ GMP $\min ^{-1}$ (mg protein) $)^{-1}$ (average of 25 assays)|.

\begin{tabular}{|c|c|c|c|c|}
\hline \multirow[b]{3}{*}{ Strain } & \multicolumn{4}{|c|}{ Enzyme derepression $(D)$} \\
\hline & \multicolumn{2}{|c|}{ IMP dehydrogenase } & \multicolumn{2}{|c|}{ GMP synthetase } \\
\hline & Adenine-grown & Guanine-grown & Adenine-grown & Guanine-grown \\
\hline \multicolumn{5}{|l|}{ Early block } \\
\hline PL1098 ( purF78) & $2 \cdot 0$ & $1 \cdot 5$ & $2 \cdot 2$ & 1.6 \\
\hline PL1075 ( purD55) & 0.9 & $0 \cdot 8$ & 0.7 & 0.7 \\
\hline \multicolumn{5}{|l|}{ AIR accumulated } \\
\hline PL1080 ( pur-60) & $3 \cdot 8$ & $3 \cdot 7$ & $4 \cdot 2$ & $4 \cdot 3$ \\
\hline PL1119 ( pur-99) & $3 \cdot 6$ & $3 \cdot 6$ & $4 \cdot 6$ & $3 \cdot 3$ \\
\hline \multicolumn{5}{|l|}{ AICAR accumulated } \\
\hline PL1086 ( purH66) & $17 \cdot 8$ & $0 \cdot 3$ & $11 \cdot 8$ & 0.4 \\
\hline PL1110 (purH90) & $18 \cdot 8$ & 0.7 & $13 \cdot 3$ & $1 \cdot 0$ \\
\hline & $1 \cdot 6^{*}$ & $0.6+$ & & \\
\hline \multicolumn{5}{|l|}{ Adenine-specific } \\
\hline MW1047 (purA747) & $1 \cdot 36$ & - & not done & - \\
\hline \multicolumn{5}{|l|}{ Guanine-specific } \\
\hline PL1138 (guaB105) & - & 0 & - & $\begin{array}{c}21.0 \\
0.7 \mathrm{~N}\end{array}$ \\
\hline PL1068 (guaA48) & - & $\begin{array}{l}58 \cdot 0 \\
1 \cdot 3 \ddagger\end{array}$ & - & 0 \\
\hline
\end{tabular}

Mutants with blocks after IMP are either adenine- or guanine-specific (Fig. 1). An adenine-specific strain (MW 1047) was repressed by growth-limiting adenine, whereas guanine-specific strains (guaA and guaB) showed very high derepression on growth-limiting guanine. The gua mutants were repressed by a higher (non-growth-limiting) concentration of guanine in the medium (Table 2).

These results suggest the involvement of both adenine and guanine derivatives in regulating the expression of the gua operon.

\section{Effect of adenine and guanine on expression of the gua operon}

The effect on expression of the gua operon of independently varying the concentrations of adenine and guanine in the growth medium was studied using the double mutants RM 1008 and RM1009. These strains cannot interconvert AMP and GMP and hence have a requirement of both adenine and guanine (Fig. 1, Table 1). The activities of IMP dehydrogenase and GMP synthetase in these strains when grown with varying concentrations of the two purines should reveal functions of their nucleotides in regulating the gua operon. The double mutants were derived from strain RM1003, an adenine-specific mutant that is negative in the Bratton-Marshall test. The mutation in strain RM1003 has been mapped at a site corresponding to the purA gene locus (Spencer \& Guest, 1973). Other mutations giving rise to a specific adenine requirement are in $\operatorname{pur} B$; these cause accumulation of SAICAR as the affected enzyme is bifunctional (Fig. 1) and the mutants are therefore positive in the Bratton-Marshall test. 
Table 3. Effects of adenine and guanine on the derepression of IMP dehydrogenase in strain RM1009 ( purA guaA)

Cultures were grown overnight in $10 \mathrm{ml}$ minimal medium supplemented with adenine and guanine (each $20 \mu \mathrm{g} \mathrm{ml} \mathrm{m}^{-1}$ ). The overnight cultures were diluted 10 -fold into minimal medium $(50 \mathrm{ml})$ supplemented with adenine and guanine (each $10 \mu \mathrm{g} \mathrm{ml}^{-1}$ ), then grown with aeration at $37^{\circ} \mathrm{C}$ for $6 \mathrm{~h}$ by which time they had reached the mid-exponential phase of growth. Finally, cultures were diluted 10 -fold into minimal medium $(200 \mathrm{ml})$ supplemented with adenine and guanine (concentrations given below). Flasks were incubated in a warm air orbital shaker at $37^{\circ} \mathrm{C}$ for $16 \mathrm{~h}$. Thiamin $\left(5 \mu \mathrm{g} \mathrm{ml}{ }^{-1}\right)$ was added to all cultures. The harvesting of bacteria, preparation of cell-free extracts and assay for IMP dehydrogenase have been described by Lambden \& Drabble (1973). Enzyme derepression $(D)$ is defined in Table 2 . The numbers in italics are the final turbidities $\left(A_{650}\right)$ of the third-stage cultures.

\begin{tabular}{|c|c|c|c|c|c|c|c|}
\hline \multirow{3}{*}{$\begin{array}{l}\text { Adenine } \\
\text { concn } \\
\left(\mu \mathrm{g} \mathrm{ml}^{-1}\right)\end{array}$} & \multicolumn{7}{|c|}{ Enzyme derepression $(D)$} \\
\hline & \multicolumn{7}{|c|}{ Guanine concn $\left(\mu \mathrm{g} \mathrm{m}^{-1}\right)$ : } \\
\hline & 1 & 2 & 3 & 4 & 5 & 6 & 10 \\
\hline 1.5 & & $\begin{array}{l}2.2^{*} \\
0.13\end{array}$ & & & & & $\begin{array}{l}2 \cdot 2 \\
0.13\end{array}$ \\
\hline $3 \cdot 5$ & $\begin{array}{l}0.4 \\
0.29\end{array}$ & & & & & & $\begin{array}{l}0.6 \\
0.24\end{array}$ \\
\hline 7 & $10 \cdot 6$ & $0.8^{*}$ & 0.8 & 0.8 & & & 0.3 \\
\hline & 0.35 & 0.42 & 0.45 & 0.45 & & & 0.39 \\
\hline 15 & $\begin{array}{l}13.0 \\
0.40\end{array}$ & $\begin{array}{c}11.7 \\
0.52\end{array}$ & $\begin{array}{l}5.9 \\
0.60\end{array}$ & $\begin{array}{l}0.7 \\
0.69\end{array}$ & & & $\begin{array}{l}0.2 \\
0.64\end{array}$ \\
\hline 20 & $\begin{array}{c}34.0 \\
0.37\end{array}$ & $\begin{array}{c}21.5 \\
0.51\end{array}$ & $\begin{array}{c}16.6 \\
0.63\end{array}$ & $\begin{array}{c}12.0 \\
0.70\end{array}$ & $\begin{array}{l}3.9 \\
0.83\end{array}$ & $\begin{array}{l}1.6 \\
0.82\end{array}$ & $\begin{array}{l}0.9 \\
0.85\end{array}$ \\
\hline 35 & $\begin{array}{r}40.5 \\
0.35\end{array}$ & $\begin{array}{r}34.7^{*} \\
0.55\end{array}$ & $\begin{array}{c}29.6 \\
0.66\end{array}$ & $\begin{array}{c}21.9 \\
0.76\end{array}$ & $\begin{array}{c}13 \cdot 0 \\
0.90\end{array}$ & $\begin{array}{c}13.1 \\
0.93\end{array}$ & $\begin{array}{l}1.6 \\
1.06\end{array}$ \\
\hline 50 & $\begin{array}{c}41.7 \\
0.37\end{array}$ & $\begin{array}{c}42.9 \\
0.57\end{array}$ & $\begin{array}{c}35.5 \\
0.68\end{array}$ & $\begin{array}{c}28.9 \\
0.78\end{array}$ & $\begin{array}{c}22.5 \\
0.89\end{array}$ & $\begin{array}{c}17.5 \\
0.95\end{array}$ & $\begin{array}{l}4 \cdot 5 \\
1 \cdot 16\end{array}$ \\
\hline 65 & $\begin{array}{c}43 \cdot 1 \\
0.35\end{array}$ & $\begin{array}{c}45.6 \\
0.56\end{array}$ & $\begin{array}{c}39.1 \\
0.67\end{array}$ & $\begin{array}{c}36.0 \\
0.80\end{array}$ & $\begin{array}{c}23.5 \\
0.95\end{array}$ & $\begin{array}{c}25.4 \\
0.98\end{array}$ & $\begin{array}{c}11.4 \\
1.22\end{array}$ \\
\hline 75 & $\begin{array}{c}48 \cdot 2 \\
0.35\end{array}$ & $\begin{array}{c}50.9 \\
0.56\end{array}$ & $\begin{array}{c}46.0 \\
0.66\end{array}$ & $\begin{array}{c}40.8 \\
0.79\end{array}$ & $\begin{array}{c}31.2 \\
0.94\end{array}$ & $\begin{array}{c}30.0 \\
0.98\end{array}$ & $\begin{array}{c}18.0 \\
1.24\end{array}$ \\
\hline 90 & $\begin{array}{r}54.0 \\
0.35\end{array}$ & $\begin{array}{r}49.1^{*} \\
0.55\end{array}$ & $\begin{array}{c}40.2 \\
0.66\end{array}$ & $\begin{array}{c}44.9 \\
0.78\end{array}$ & $\begin{array}{c}32.0 \\
0.96\end{array}$ & $\begin{array}{c}34.9 \\
0.94\end{array}$ & $\begin{array}{c}19 \cdot 1 \\
1.26\end{array}$ \\
\hline 140 & $\begin{array}{c}41.8 \\
0.37\end{array}$ & $\begin{array}{c}41.9 \\
0.50\end{array}$ & $\begin{array}{c}42.3 \\
0.65\end{array}$ & $\begin{array}{c}45 \cdot 6 \\
0.79\end{array}$ & $\begin{array}{c}44.0 \\
0.88\end{array}$ & $\begin{array}{c}42.3 \\
1.00\end{array}$ & $\begin{array}{c}26.9 \\
1.25\end{array}$ \\
\hline 200 & $\begin{array}{c}41 \cdot 5 \\
0.30\end{array}$ & $\begin{array}{c}46.8 \\
0.42\end{array}$ & $\begin{array}{c}43.1 \\
0.57\end{array}$ & $\begin{array}{c}41.8 \\
0.68\end{array}$ & $\begin{array}{c}37.9 \\
0.82\end{array}$ & $\begin{array}{c}32.6 \\
0.93\end{array}$ & $\begin{array}{c}27.9 \\
1.22\end{array}$ \\
\hline
\end{tabular}

* The corresponding values for the derepression of GMP synthetase for cultures of RM1008 (purA guaB) supplemented with $2 \mu \mathrm{g}$ guanine $\mathrm{ml}^{-1}$ and $1 \cdot 5,7,35$ and $90 \mu \mathrm{g}$ adenine $\mathrm{ml}^{-1}$ are $0 \cdot 3,4 \cdot 5.13 \cdot 2$ and $14 \cdot 0$, respectively.

Low concentrations of guanine allowed full derepression in guanine-specific mutants whereus high concentrations repressed enzyme formation (Table 2). The effective range of adenine concentrations for the double mutants was therefore determined with guanine set at a low concentration $\left(2 \mu \mathrm{g} \mathrm{ml}^{-1}\right)$ so that it did not repress the enzymes (Table 3 ). Under these conditions the amount of derepression of both IMP dehydrogenase and GMP synthetase increased with increasing adenine concentration (Table 3 ).

The effect of independently varying both adenine and guanine concentrations on the production of IMP dehydrogenase was examined in strain RM1009 (Table 3). For any particular concentration of guanine an increase in the adenine concentration enhanced derepression of the enzyme. Conversely, for any concentration of adenine an increase in the guanine concentration repressed IMP dehydrogenase. Above about $90 \mu \mathrm{g}$ adenine $\mathrm{ml}^{-1}$, however, IMP dehydrogenase production was often reduced as was the final yield of bacteria. Growth inhibition by adenine has been observed previously (Dalal et al., 1966; Mosteller \& Goldstein. 1975). The derepression (D) of IMP dehydrogenase measured for each guanine 


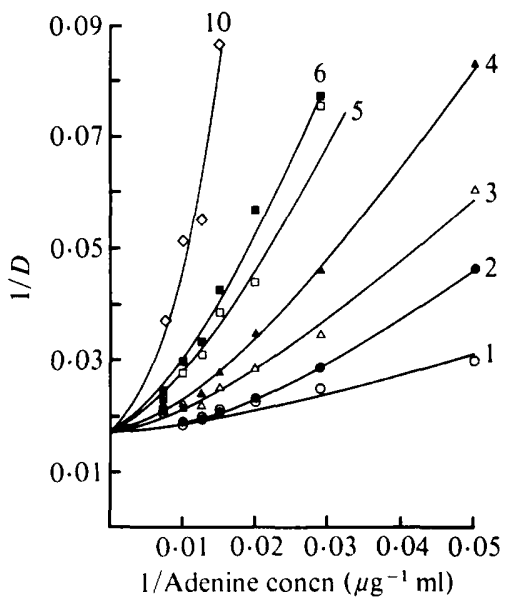

Fig. 2

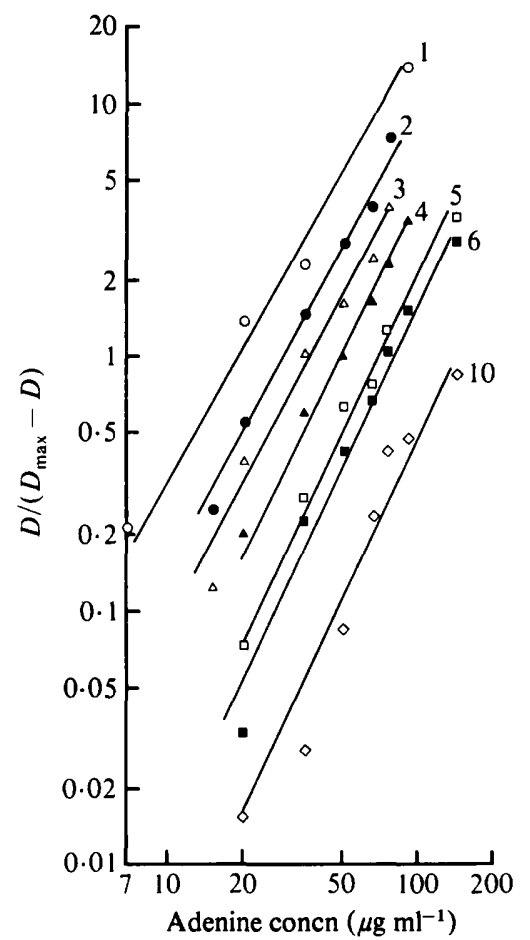

Fig. 3

Fig. 2. Derepression $(D)$ of IMP dehydrogenase in strain RM1009 (purA guaA) grown with various concentrations of adenine and guanine. Numbers on the curves refer to the initial guanine concentration $\left(\mu \mathrm{g} \mathrm{ml}^{-1}\right)$ in the growth medium. The data are taken from Table 3.

Fig. 3. Data from Table 3 presented as Hill plots. Numbers on the lines refer to the initial guanine concentration $\left(\mu \mathrm{g} \mathrm{ml}^{-1}\right)$ in the growth medium.

concentration plotted against adenine concentration generates a family of sigmoidal saturation curves (not shown) that are indicative of a cooperative process. A double reciprocal plot (Fig. 2) of the data produces upward-curving lines; these meet on the $y$ axis at a value corresponding to $D_{\max }=58$. The maximal derepression measured for a culture of a guaA mutant is also 58-fold (Table 2). The data substituted into the Hill equation (Levitzki, 1978):

$$
\log \left[D /\left(D_{\max }-D\right)\right]=n \cdot \log [\text { adenine }]-\log \mathrm{K}
$$

results in a series of parallel straight lines of slope $n=2$ (Fig. 3). Therefore, any particular level of enzyme derepression corresponds to a precise ratio of adenine to guanine concentrations. For half-maximal derepression $\left[D /\left(D_{\max }-D\right)=1\right]$ the average ratio of adenine to guanine concentrations determined from Fig. 3 is approximately $13 \cdot 5$. There is no change in cooperativity in the system when the guanine concentration is varied within the limits shown.

\section{Expression of the gua operon in an AICAR-accumulating mutant}

Strain PL1110, an AICAR-accumulating mutant, is derepressed for the gua operon when provided with growth-limiting adenine but not with growth-limiting guanine or hypoxanthine nor when adenine is provided in excess (Table 2). Changes in the specific activity of IMP dehydrogenase throughout growth of this strain with $4 \mu \mathrm{g}$ adenine $\mathrm{ml}^{-1}$ are shown in Fig. $4(a)$. Derepression was maximal at the beginning of the stationary phase. IMP dehydrogenase was completely repressed throughout the growth of a similar culture provided with growth-limiting guanine (Fig. $4 a$ ). 


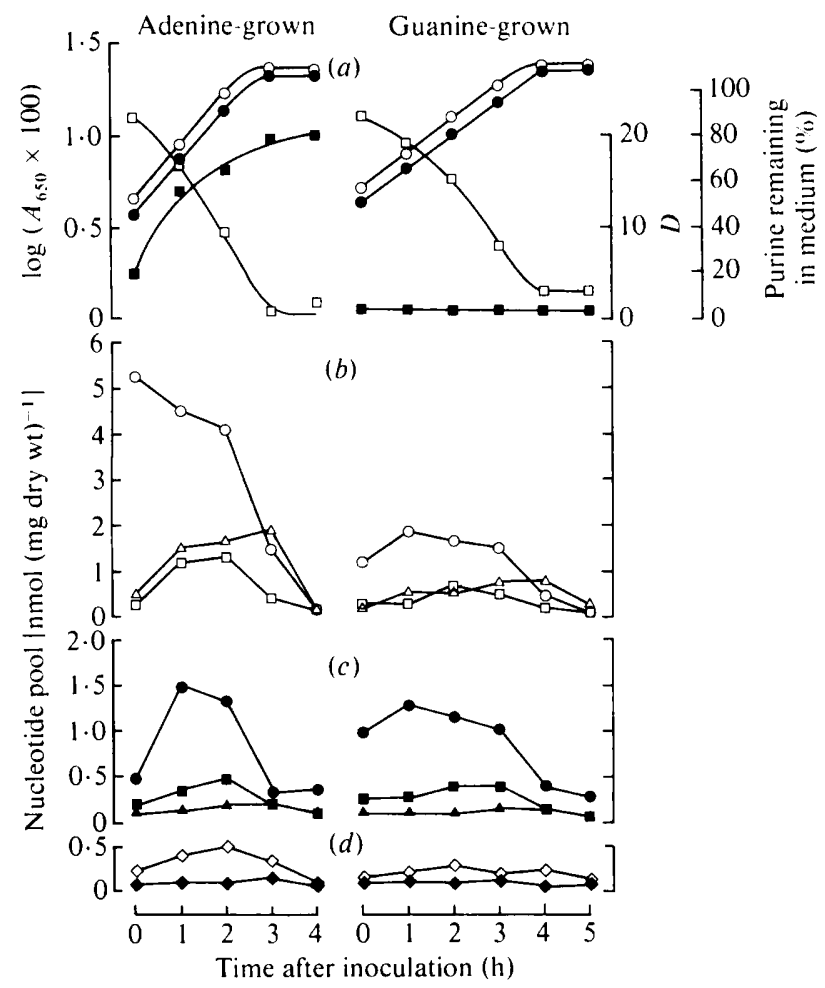

Fig. 4. Derepression of IMP dehydrogenase in a purH mutant (PL1110) and the corresponding intracellular purine nucleotide pools. Bacteria were inoculated into $20 \mathrm{ml}$ minimal medium supplemented with either $28 \mu \mathrm{g}$ adenine $\mathrm{ml}^{-1}$ or $31 \mu \mathrm{g}$ guanine $\mathrm{ml}^{-1}$ (i.e. both $0.2 \mathrm{~mm}$ ). Cultures were incubated overnight at $37^{\circ} \mathrm{C}$ followed by 10 -fold dilution into $8 \mathrm{ml}$ minimal medium at $37^{\circ} \mathrm{C}$ supplemented with ${ }^{14} \mathrm{C}$-labelled adenine or guanine, respectively $\left(0.2 \mathrm{mM}\right.$; specific radioactivity $\left.12 \mu \mathrm{Ci} \mu \mathrm{mol}^{-1}\right)$. After three generations bacteria from $7 \mathrm{ml}$ of each ${ }^{14} \mathrm{C}$-labelled culture were washed with cold minimal medium and resuspended in $7 \mathrm{ml}$ minimal medium. Labelled cells were then diluted 10 -fold into $60 \mathrm{ml}$ pre-warmed medium containing adenine or guanine, respectively $\left(0.02 \mathrm{~mm} ; 12 \mu \mathrm{Ci} \mu \mathrm{mol}^{-1}\right)$. These final-stage cultures were incubated at $37^{\circ} \mathrm{C}$ with shaking and samples $(10 \mathrm{ml})$ were withdrawn hourly for extraction of intracellular nucleotides (see Methods) and determination of purine uptake from the medium (estimated from residual radioactivity of the culture filtrate). IMP dehydrogenase was assayed in samples $(200 \mathrm{ml})$ taken from larger unlabelled cultures (scaled up 50 -fold, but otherwise identical conditions) grown in parallel with forced aeration and stirring. Thiamin $\left(5 \mu \mathrm{g} \mathrm{ml}^{-1}\right)$ was added to all adenine-grown cultures. (a) Growth curves for unlabelled cultures $(O)$ and relative specific activity $(D)$ of IMP dehydrogenase ( $\square$ ); growth curves for ${ }^{14} \mathrm{C}$-labelled cultures $(O)$ and purine remaining in the medium ( $\square$ ) expressed as a percentage of the starting concentration. (b) Adenylate pools: ATP $(O)$, ADP $(\square)$, AMP $(\triangle) .(c)$ Guanylate pools: GTP $(\bullet)$, GDP $(\boldsymbol{\square})$, GMP $(\Delta)$. (d) IMP pool $(\diamond)$, XMP pool $(\bullet)$.

\section{Intracellular purine nucleotide pools in an AICAR-accumulating mutant}

Strain PL1110 was labelled under purine-limiting conditions either with $\left[8^{-14} \mathrm{C}\right]$ adenine or $\left[8-{ }^{14} \mathrm{C}\right]$ guanine. Figure $4(b, c, d)$ shows the pools of individual purine nucleotides in the bacteria prior to and during purine starvation. The relative specific activities $(D)$ of IMP dehydrogenase in bacteria taken from unlabelled cultures grown in parallel are also indicated (Fig. $4 a$ ). Labelled and unlabelled cultures were grown under identical conditions and the bacteria divided with the same mean generation time $(1.25 \mathrm{~h}$ with adenine limitation, $1.7 \mathrm{~h}$ with guanine limitation). The only pools showing significant differences between the adenineand guanine-starved cultures are those for adenine nucleotides; at any particular time during exponential growth the total adenylate pool in guanine-grown cells was two to three times less than that of adenine-grown cells. The adenylate pool in the guanine-grown bacteria was in 
Table 4. Correlation between enzyme derepression and the concentrations of extra-and intracellular purines

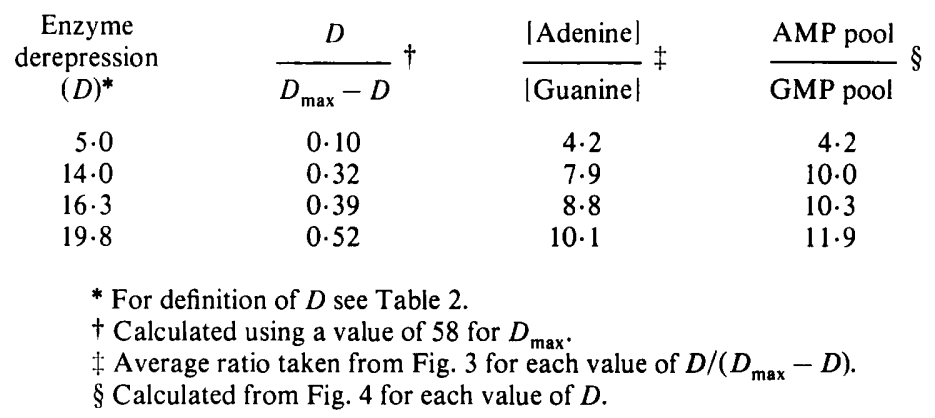

fact well below the range of values previously measured for $E$. coli under a wide variety of culture conditions (Knowles, 1977). In both cultures the ADP and ATP pools diminished throughout purine depletion whereas the AMP pool showed a steady increase.

The relative sizes of the AMP and GMP pools throughout exponential growth of strain PL1110 and the corresponding derepression of IMP dehydrogenase can be compared with the ratio of adenine to guanine in the culture medium needed to achieve the same derepression in strain RM1009 (Table 4). A close correlation is revealed, for each level of enzyme derepression in the two strains, between the ratio of the endogenous AMP and GMP pools and the ratio of adenine to guanine provided in the culture medium.

\section{DISCUSSION}

Expression of the gua operon in purine auxotrophs depends on both the position of the block in purine biosynthesis and the nature of the purine supplement provided. Maximum expression occurs with gua mutants growth-limited by guanine depletion when, presumably, the intracellular concentrations of guanine nucleotides are at their lowest. This suggests that the gua operon is normally repressed by guanine nucleotides.

With AICAR-accumulating mutants derepression of enzyme synthesis occurs when adenine, but not guanine, is growth-limiting. These strains are unable to convert adenine to GMP via AICAR, but do so through adenosine and its subsequent deamination to inosine by adenosine deaminase (Fig. 1). They accumulate AICAR by biosynthesis de novo and also as a by-product of the histidine pathway. The dephosphorylated form of AICAR is a potent inhibitor of adenosine deaminase (Kuramitsu et al., 1964) and may restrict conversion of adenine to GMP. During growth on adenine this restriction could lead to low intracellular concentrations of guanine nucleotides, a necessary precondition for derepression of the gua operon. At the same time the supply of adenine nucleotides remains adequate for growth because it is maintained from an exogenous source of adenine. GMP is freely convertible to AMP in AICAR-accumulating mutants (Fig. 1); thus bacteria growing in a guaninesupplemented medium would maintain a balance between intracellular adenylate and guanylate pools. During guanine starvation both pools would contract in parallel, and if guanine nucleotides alone were responsible for controlling expression of the gua operon, derepression would occur. The absence of derepression indicates an involvement of adenine nucleotides in the control.

AMP and GMP are freely interconvertible in mutants blocked before AICAR. Growth limitation by adenine or guanine would produce a concomitant contraction of both adenylate and guanylate pools. Thus the conditions for derepression of the gua operon (depletion of the guanylate pool in advance of the adenylate pool) are not fully realized. 
The involvement of both guanine and adenine nucleotides in controlling expression of the gua operon is clearly revealed in double mutants blocked in both GMP and AMP biosynthesis (Fig. 1). The concentrations of guanine and adenine in the culture medium can be varied independently with no possibility of their metabolic interconversion. The extent of derepression depends on the relative concentrations of the two purines, most derepression being achieved at the greatest adenine to guanine ratio. Half the maximal (58-fold) derepression observed with a guanine-starved guaA mutant corresponds to a purine ratio of about $13 \cdot 5$. The empirical relationship between enzyme derepression and purine concentration suggests a cooperative process and could be a manifestation of interactions between the purine nucleotides and a cytoplasmic regulatory protein for the gua operon. It should be noted that the purine uptake systems of $E$. coli do not display cooperativity, but rather Michaelis-Menten kinetics (Hochstadt-Ozer \& Stadtman, 1971b; Jackman \& Hochstadt, 1976).

Extracellular purines are readily taken up by $E$. coli, being first converted to nucleotides by specific phosphoribosyltransferases (Hochstadt-Ozer \& Stadtman, 1971b; Jackman \& Hochstadt, 1976). Intracellular purine nucleotide pools, however, need not vary proportionally with the concentration of purine base supplied in the medium. Purine phosphoribosyltransferases are susceptible to product inhibition and this may regulate the intracellular concentrations of nucleotides (Hochstadt-Ozer \& Stadtman, 1971a). It is therefore more appropriate to make direct measurements of the concentrations of purine nucleotides in bacteria and seek relationships between these and the extent of derepression of the gua operon. A similar approach has been used to identify putative repressing metabolites of pyrimidine biosynthesis in $E$. coli (Kelln et al., 1975). In neither adenine- nor guanine-starved cultures of the AICAR-accumulating mutant PL1110 did the total guanylate pool exceed $2 \mathrm{nmol}(\mathrm{mg} \text { dry } \mathrm{wt})^{-1}$. This value must be below that required for repression of the gua operon because IMP dehydrogenase was derepressed in adenine-starved bacteria. Despite the low concentration of guanylate, IMP dehydrogenase was repressed in guanine-starved bacteria which had unusually small adenylate pools. It appears, therefore, that one or more adenine nucleotides may 'induce' the synthesis of this enzyme, a 2- to 3-fold variation in the adenylate pool being sufficient for 19-fold derepression. Identification of the particular purine nucleotides controlling the gua operon is not possible from the available data, but the intracellular AMP and GMP concentrations of the adenine-starved culture correlate with the extracellular adenine to guanine ratios associated with various degrees of enzyme derepression in the double mutant.

In summary, the observed pattern of enzyme derepression in purine auxotrophs is consistent with a dual induction-repression mechanism for regulating the gua operon. The system responds not only to variations in the absolute amount of endogenous GMP but to its concentration relative to AMP. This control ensures close coupling of GMP biosynthesis to that of AMP and allows derepression of the gua operon only when the available AMP is adequate for cell growth and division.

\section{REFERENCES}

Dalal, F. R., Gots, R. E. \& Gots, J. S. (1966). Mechanism of adenine inhibition in adenine-sensitive mutants of Salmonella typhimurium. Journal of Bacteriology 91, 507-513.

DAvidson, J. N. (1976). The Biochemistry of the Nucleic Acids, 8th edn. London: Chapman \& Hall.

Davis, B. D. \& Mingioli, E. S. (1950). Mutants of Escherichia coli requiring methionine or vitamin B 12. Journal of Bacteriology 60, 17-28.

Gilbert, H. J., Lowe, C. R. \& Drabble, W. T. (1979). Inosine $5^{\prime}$-monophosphate dehydrogenase of Escherichia coli: purification by affinity chromatography, subunit structure and inhibition by guanosine $5^{\prime}$-monophosphate. Biochemical Journal $183,481-494$.

Gots, J. S. \& Gollub, E. G. (1957). Sequential blockade in adenine biosynthesis by genetic loss of an apparent bifunctional deacylase. Proceedings of the National Academy of Sciences of the United States of America 43, 826-834.

Hochstadt-Ozer, J. \& Stadtman, E. R. (1971a). The regulation of purine utilization in bacteria. $I$. Purification of adenine phosphoribosyltransferase from Escherichia coli $\mathrm{K} 12$ and control of activity by nucleotides. Journal of Biological Chemistry 246, 5294-5303. 
Hochstadt-Ozer, J. \& Stadtman, E. R. (1971b). The regulation of purine utilization in bacteria. II. Adenine phosphoribosyltransferase in isolated membrane preparations and its role in transport of adenine across the membrane. Journal of Biological Chemistry' 246, 5304-5311.

JACKMAN, L. E. \& HochstadT, J. (1976). Regulation of purine utilization in bacteria. VI. Characterisation of hypoxanthine and guanine uptake into isolated membrane vesicles from Salmonella typhimurium. Journal of Bacteriology 126, 312-326.

Kelln, R. A., Kinahan, J. J., Foltermann, K. F. \& O'Donovan, G. A. (1975). Pyrimidine biosynthetic enzymes of Salmonella typhimurium, repressed specifically by growth in the presence of cytidine. Journal of Bacteriology 124, 764-774.

KNOWLES, C. J. (1977). Microbial metabolic regulation by adenine nucleotide pool. Symposia of the Society for General Microbiology 27, 241-283.

Kuramitsu, H. K., Udaka, S. \& Moyed, H. S. (1964). Induction of inosine $5^{\prime}$-monophosphate dehydrogenase and xanthosine 5'-monophosphate aminase by ribosyl-4-amino-5-imidazolecarboxamide in purine-requiring mutants of Escherichia coli B. Journal of Biological Chemistry 239, 3425-3430.

LAMBdEN, P. R. (1972). Gene-enzyme relationships in the purine pathway of Escherichia coli. Ph.D. thesis, University of Southamptom.

Lambden, P. R. \& Drabble, W. T. (1973). The gua operon of Escherichia coli K-12: evidence for polarity from guaB to guaA. Journal of Bacteriology 115. 992-1002.

LEVITZKI, A. (1978). Quantitative Aspects of Allosteric Mechanisms. Berlin: Springer-Verlag.

LuRIA, S. E. (1960). In The Bacteria, vol. 1, pp. 18-19. Edited by I. C. Gunsalus \& R. Y. Stanier. New York: Academic Press.

Mager. J. \& Magasanik, B. (1960). Guanosine 5 -monophosphate reductase and its role in the interconversion of purine nucleotides. Journal of Biological Chemistry 235, 1474-1478.
Mosteller, R. E. \& Goldstein, R. V. (1975). Unusual sensitivity of Escherichia coli to adenine or adenine plus histidine. Journal of Bacteriology 123, 750-751.

NAZAR, R. N., LAWford, H. G. \& Wong, J. T. (1970). An improved procedure for extraction and analysis of cellular nucleotides. Analytical Biochemistry 35, 305-313.

Neuhard, J. \& Munch-Peterson, A. (1966). The acid-soluble nucleotide pool in thymine-requiring mutants of Escherichia coli during thymine starvation. II. Changes in the amounts of deoxycytidine triphosphate and deoxyadenosine triphosphate in Escherichia coli $15 \mathrm{~T}^{-} \mathrm{A}^{-} \mathrm{U}^{-}$. Biochimica et biophysica acta 114,61-71.

Nierlich, D. P. \& Magasanik, B. (1971). Control by feedback repression of the enzymes of purine biosynthesis in Aerobacter aerogenes. Biochemica et biophysica acta 230, 349-361.

NiJKAMP, H. J. J. (1969). Regulatory role of adenine nucleotides in the biosynthesis of guanosine $5^{\prime}$ monophosphate. Journal of Bacteriology 100, 585593.

Nijkamp. H. J. J. \& DehaAn, P. G. (1967). Genetic and biochemical studies of the guanosine $5^{\prime}$-monophosphate pathway in Escherichia coli. Biochimica et biophysica acta 145, 31-40.

SPENCER, M. E. \& Guest, J. R. (1973). Isolation and properties of fumarate reductase mutants of Escherichia coli. Journal of Bacteriology 114, 563-570.

WATSON, M. D. (1977). The biochemical genetics of purine nucleotide synthesis in Escherichia coli. Ph.D. thesis, University of Southampton.

Watson, M. D. \& DrabBle, W. T. (1975). Relationship between purine nucleotide biosynthesis and requirement for thiamine in Escherichia coli $\mathrm{K} 12$. Proceedings of the Society for General Microbiology 2, 44-45.

WyngaARDEN, J. B. \& Greenland, R. A. (1963). The inhibition of succinyladenylate kinosynthetase of Escherichia coli by adenosine and guanosine 5'monophosphates. Journal of Biological Chemistry 238, 1054-1057. 